\title{
Społeczeństwo poznańskie z perspektywy onimicznej - wstępna rekonstrukcja badawcza ${ }^{1}$
}

Mikrospołeczność, którą opisuję $\mathrm{w}$ artykule, to grupa zamieszkująca w okresie od XVII do XVIII wieku tereny należące do parafii św. Wojciecha. Był to obszar położony na lewym brzegu Warty, na północnym zachodzie, poza murami obronnymi miasta, czyli tzw. przedmieście św. Wojciecha wraz z przedmieściem wronieckim i dawne podpoznańskie wsie Golęcin, Jeżyce, Kundorf, Naramowice, Nowa Wieś, Piątkowo, Sołacz, Strzeszyn, Sytkowo, Szelag, Umultowo, Urbanowo, Urbanówko i Winiary. Pozycja społeczna osób zamieszkujących tereny parafii była zróżnicowana, gdyż przynależne jej obszary reprezentowały różne typy własności. Przedmieście wronieckie podlegało administracyjnie władzy miejskiej. Osada wokół kościoła św. Wojciecha była jurydyką kościelną należącą do kapituły poznańskiej, natomiast wchodzące w skład parafii wioski stanowiły własność szlachecką (np. Umultowo, Nowa Wieś, Naramowice) albo kościelną, a część wsi stanowiła własność miasta (Jeżyce, Kundorf, Sołacz czy Winiary)². Mieszkańcy przedmieścia wronieckiego i jurydyki św. Wojciecha byli ludźmi wolnymi, a w ksieggach miejskich występowali jako mieszczanie. Wobec mieszkańców jurydyki kapitule poznańskiej przysługiwały pewne uprawnienia zwierzchnie, ograniczające ich swobodę osobistą. Właściciel pobierał od nich czynsz, płacony od wszelkich posiadanych gruntów, nie wolno było im też przyjmować prawa miejskiego

${ }^{1}$ Praca naukowa finansowana ze środków na naukę w latach 2006-2009 (projekt badawczy Nr H01 D 04230 pod kierunkiem prof. dr hab. I. Sarnowskiej-Giefing pt. Nazwiska mieszkańców Poznania na tle antroponomastykonu innych miast wielkopolskich i ewolucji polskiego systemu antroponimicznego).

${ }^{2}$ Z. Kurzawa, A. Kusztelski, Kościót św. Wojciecha, Poznań 2003, s. 12-13. 
w Poznaniu. Przedmieście i jurydykę zamieszkiwali głównie rzemieślnicy³, którzy w stosunku do ludności mieszkającej w obrębie murów miejskich stanowili uboższą część społeczności

Jak wspomniałam, w skład parafii św. Wojciecha wchodziły również osady wiejskie - wsie, należące do szlachty, kościoła, a także stanowiące własność miejską. Poznań jeszcze w XVI wieku włączył się w proces rozwijania gospodarki folwarcznej, nabywając na własność podpoznańskie wsie i folwarki, które dostarczały miastu dochodów i wielu produktów na rynek lokalny. $\mathrm{Na}$ początku XVII wieku w dobrach ziemskich Poznania posługiwano się pracą chłopów pańszczyźnianych zamieszkujących wsie miejskie, ale także wykorzystywano pracę najemną. Stąd też wsie należące do miasta zamieszkiwali poza chłopami pańszczyźnianymi wolni najemcy ${ }^{5}$. W początkach XVIII wieku zniszczenia po wojnie polsko-szwedzkiej oraz zaraza morowa doprowadziły do wyludnienia wsi miejskich. Miastu brakowało środków na ich odbudowę, w związku z czym sprowadzono osadników. Wiązało się to z przejściem od gospodarki folwarczno-pańszczyźnianej do gospodarki czynszowej. Oparcie się na osadnictwie polskim okazało się niewystarczające, stad starano się ściagnąć osadników niemieckich. Jednakże, aby zachować katolicki charakter osadnictwa, zwrócono się do ludności z okolic Bambergu. Osadnicy, zarówno polscy, jak i niemieccy, mieli wolność osobistą, opłacali czynsz, a posiadane przez nich grunty były dziedziczone ${ }^{6}$.

Mając na uwadze ustalenia historyków i innych badaczy społeczności Poznania, omówię zgromadzony przeze mnie materiał antroponimiczny. Wyniki uzyskane $\mathrm{z}$ analizy jednego typu polskojęzycznych nazwisk, tj. nazwisk utworzonych w wyniku nominacji odapelatywnej, skonfrontuję z wnioskami pozajęzykowymi. W artykule omówię zatem charakterystyczne cechy społeczności świętowojciechowskiej, przy czym istotne będą dla mnie zarówno wnioski socjologiczne (np. typy zawodów, pełnione funkcje), jak i filologiczne (np. słownictwo, słowotwórstwo). Materiał badawczy, który wykorzystam

${ }^{3}$ Z. Kulejewska, Ustrój prawny jurydyk, w: Dzieje Poznania, t. 1, red. J. Topolski, Warszawa-Poznań 1988, s. 407-408.

${ }^{4}$ S. Abt, Ludność Poznania w XVII i pierwszej połowie XVIII wieku, w: Dzieje Poznania, t. 1, red. J. Topolski, Warszawa-Poznań 1988, s. 449-454.

${ }^{5}$ M. Drozdowski, Wsie i folwarki Poznania, w: Dzieje Poznania, t. 1, red. J. Topolski, Warszawa-Poznań 1988, s. 472-474.

${ }^{6}$ K. Kuklińska, Gospodarka, w: Dzieje Poznania, t. 1, red. J. Topolski, Warszawa-Poznań 1988, s. 658-659. 
podczas analizy, to około 1000 oznaczeń osobowych (nazwisk, pierwotnych przezwisk i przydomków), wyekscerpowanych z siedemnasto- i osiemnastowiecznych ksiag metrykalnych poznańskiej parafii św. Wojciecha ${ }^{7}$. Ze względu na wstępny charakter moich badań rezygnuję z podawania szczegółowych danych liczbowych ${ }^{8}$.

Semantyka podstaw derywacyjnych badanych antroponimów pozostaje w ścisłym związku ze światem roślin i zwierząt, zjawiskami kultury materialnej i duchowej opisywanej społeczności. Przyjęta w pracy klasyfikacja materiału nawiązuje do propozycji Zofii Kowalik-Kalety ${ }^{9}$. Uwzględniając specyfikę nazewnictwa poznańskiego, wyróżniam cztery grupy: do pierwszej zaliczam te antroponimy (przezwiska i przydomki), które opisują cechy zewnętrze nosiciela (cechy zewnętrzne); do drugiej włączam nazwy osobowe charakteryzujące cechy wewnętrzne, a więc cechy charakteru, usposobienia i zachowania oraz cechy moralne (cechy psychiczne); podstawą trzeciej grupy, nazwanej za Z. Kowalik-Kaletą, interakcje ze światem zewnętrznym, są nazwiska wskazujące na wykonaną lub stale wykonywaną czynność lub wydarzenie, w którym człowiek brał udział (wyrażały to pospolite nazwy przedmiotów charakterystycznych dla tej czynności lub wydarzenia), albo na stan czy proces, który stał się udziałem człowieka (wyrażały to nazwy nosicieli stanów i procesów); w czwartej grupie umieszczam nazwiska charakteryzujące człowieka przez jego miejsce w społeczeństwie: znalazły się tu zatem miana wskazujące na kondycję majątkowo-społeczną człowieka (wykonywany zawód, zajmowany urząd czy stanowisko) oraz charakteryzujące go przez relacje rodzinne. Szczegółowy podział przedstawia się następująco.

\section{Cechy zewnętrzne}

Apelatywy motywujące nazwy osób pomieszczonych w tej grupie wskazywać mogły:

${ }^{7}$ Najstarsza zachowana księga pochodzi z 1609 roku, najmłodsza z 1799. Są to księgi narodzin i chrztów (LB), małżeństw (LC) oraz zgonów (LM). Obecnie dokumenty te, zarówno w postaci oryginalnej, jak i w postaci zmikrofilmowanej, znajdują się w Archiwum Archidiecezjalnym w Poznaniu.

${ }^{8}$ Spodziewam się, że liczba nazwisk odapelatywnych w gromadzonym materiale może wzrosnąć. Całościowy obraz badanej społeczności, i nie tylko z perspektywy nazwisk odapelatywnych, przedstawię w przygotowywanej rozprawie doktorskiej.

${ }^{9}$ Z. Kowalik-Kaleta, Historia nazwisk polskich na tle społecznym i obyczajowym (XII-XV wiek), Warszawa 2007. 
- wzrost i budowę ciala: CHUDY 1636, HUDY 1647 (RNP I 87 - od chudy: Chudy 1390) ${ }^{10}$, DROBNY 1685 (RNP I 149 - od drobny: Drobny 1397) ${ }^{11}$; DŁUGOSZ 1689 (RNP I 136 - od długosz 'człowiek wysoki’: Długosz 1317), WIELIK 1762 (RNP II 675 - od wielki, stp. też wieliki, wielgi, wieligi: Wielik), KROTKY 1644 (RNP I 467 - od krótki: Krótki 1601), KUSY 1674 (RNP I 496 - od stp. kusy 'krótki': Kusy 1513), MAŁY 1638 (RNP II - od mały, Mały 1376), BRZUSZKO 1668 (RNP I 58 - od brzuszko: Brzuszko 1437), PĘKATY 1649 (RNP II 227 - od pękaty 'pełny, gruby': Pękaty 1494), KROWIGĘBA 1629 (od krowi 'mający związek z krową' Sstp, gęba 'twarz' Sstp), metaf. 'ten, kto miał twarz jak krowa';

- kolor włosów: BIAŁŁY 1635 (RNP I 32 - od podstawy biat-, w pochodnych od biel-, bil-: Biały 1399), BIAŁAS 1612 (RNP I 32 - od podstawy biat-, w pochodnych od biel-, bil-: Białaś, Bielas 'człowiek o białych włosach' 1548), KOSMATA, n.ż. 1649 (RNP I 446 - od kosmaty 'kudłaty': Kosmaty 1400), RUDY 1765 (RNP II 369 - od rudy 'koloru rdzy, czerwonobrązowy'), KUDŁA 1630 (RNP I 485 - od kudet 'włos': Kudła 1399);

- części ciała: DUPA 1648 (RNP I 158 - od dupa: Dupa 1425), GŁOWA 1612 (RNP I 241 - od głowa: Głowa 1382), KOLANKO 1611 (RNP I 425 - od kolano lub od kolanko: Kolanko 1492), KARCH 1614 (RNP I 377 - od podstawy karch-, por. karchut 'lewa ręka': Karch 1410), OCZKO 1623, n.ż. (RNP II 175 - od oczko: Oczko 1224);

- kondycję fizyczną, urodę lub ułomność, choroby, wiek: BUŁA 1626 (RNP I 61 - od podstawy bul-, por. bula, buła 'zgrubienie, guz', psł. *buliti 'obrzmiewać, pęcznieć; wytrzeszczać oczy', ale i gw. bula 'byk', buła, dawniej też boła, bulla 'dekret': Bula, Buła 1536), KULAWY 1682 (RNP I 488 - od kulawy: Kulawy 1486), MORA 1634, n.ż. (RNP II 115 - od podstawy

10 Przykładowe nazwy osób umieszczam wraz z datą stanowiącą najstarsze poświadczenie źródłowe (np. KULAWY 1682). Za Kazimierzem Rymutem (RNP) w nawiasie orientacyjnie podaję wybrane motywacje omawianych antroponimów oraz odnotowuję staropolskie poświadczenie interesującego mnie antroponimu wraz z datą, jeśli oczywiście takie istnieje (np. Kulawy 1486).

11 Do nielicznych należą określenia osób wysokich. Warto jednak tu nadmienić, że bardzo licznie reprezentowana jest w badanym materiale jeżycka rodzina nazywana zestawieniem Wielki Wojtek 1765. Por. fragment tekstu: ,[...] bapt. infantem noe Mariannam L.L. Mathia et Catharina WielkoWoytkow con. leg.de Jezyce [...]” - 1766/LB 1761-1789/56; „,...] bapt. Joannem L.L. Mathia et Catharina Wielkichwoytkow de Jezyce [...]” - 1770/LB 1761-1789/98; „L. Marianna Wielkowoytkowa de Jezyce [podkr. - A.K.T.]" - 1771/LB 1761-1789/106. Jeżyce zamieszkiwała również rodzina Małych Wojtków 1764 (por. Mały Woytek, Mała Woytkowna). Por. fragment tekstu: „Laboriosus Nicolaus Mały Woytek” - 1787/LB 1761-1789/297; „[...] bapt. infantem nomine Andream Lab. Nicolai et Magdalenae Małych Woytkow con. leg. Jezyce [...]" - 1790/LB 1790-1806/17; ,„pudica Elisabetha mała woytkowna de Jezyce” - 1784/LB 1761-1789/253. 
mor-, por. mór 'zaraza', mor 'czarny', mora 'chorobliwy odór', morzyć: Mora 1425), OBROSTEK 1609, n.ż., OBROSTEK 1614 (RNP II 170 - od obrość 'zarosnąć', obrosty 'zarośnięty': por. Obrosły), PIĘKNY 1635 (RNP II 237 od piękny 'ładny, śliczny’: Piękny 1602), ROZMAITY 1703 (RNP II 364 - od rozmaity 'różniący się kształtem i postacią'), STARY 1652 (RNP II 477 - od stary: Stary 1396), STROIFĄS 1698 (RNP II 493 - od stroić dawniej 'czynić robić', też 'upiększać, ubierać' i od wass: Strojwąs, Stroiwąs), ZDECHLIK 1626 (RNP II 733 - od zdechty, stp. zdech 'skonanie': Zdechlik);

- sposób mówienia: BASIK 1695 (RNP I 22 - od bas 'niski głos męski, człowiek mówiący niskim głosem'), BURCZAŁA 1611 (od burczeć 'krzyczeć; warczeć'), KNYCHAŁA 1700 (RNP I 417 - od gw. knychać 'chrząkać': Knychała 1595), SWIST 1690 (RNP II 951 - od świst 'ostry dźwięk': Swist), SYKORZ 1652 (RNP II 514 - od sykać 'wydawać syk', syk: Sykorz), RYCZEL 1769 (RNP II 375 - od ryczeć 'wydawać doniosły, przeciagły głos’: Ryczel), RYK 1761 (RNP II 376 - od ryk 'donośny, przeciagły głos', też stp. termin sądowy rykać, ryknać: Ryk 1360), WRZASKA 1666 (RNP II 705 - od wrzask 'głośny, przeraźliwy krzyk', wrzeszczeć: por. Wrzask 1478).

\section{Cechy wewnętrzne}

Apelatywy motywujące nazwiska zamieszczone w tej grupie wskazywać mogły:

- cechy negatywne: BUJAKOWA, n.ż. 1640 (RNP I 61 - od bujak' 'awanturnik; byk': Bujak 1400), BUJAN 1770 (RNP I 61 - od bujan 'zawadiaka': Bujan), BURAN 1632 (RNP I 62 - od podstawy bur-, por. bury; bura 'awantura', burak; burka 'opończa'; burza, burzyć: Buran 1711), CHAM 1700 (RNP I 72 - od cham: Cham 1259), CHYŻY 1685 (RNP I 91 - od chyży 'szybki'), CICHA 1632, n.ż. (RNP I 93 - od cichy: Cichy 1454), DŁUBAŁA 1611 (RNP I 136 - od gw. dtubała 'guzdrała': Dłubała 1618), DUSZA 1609 (RNP I 159 - od dusz, dusza: Dusza 1456), FRASZKA 1768 (RNP I 202 - od fraszka 'żart': Fraszka 1765), GNIEWEK 1610 (RNP I 244 - por. stp. gniewek 'człowiek gniewliwy, złośliwy': Gniewek 1399), GOSCINNA 1646, GOSCINNY 1665 (RNP I 258 - od gościnny: Gościnny 1691), GURNY 1783 (RNP I 255 od górny 'znajdujący się wysoko'; przenośnie ‘dumny’: Gorny 1383, Gurny), KWASNA 1703, n.ż., KWASNY 1707 (od 'kwaśny, o cierpkim smaku', także 'niezadowolony, niechętny' SXVI; RNP I 502 - od kwaśny: Kwaśny 1432), MIZERA 1705, n.ż. (RNP II 107 - od stp. mizera 'bieda, nikczemność': Mizera 1478), MRZYGŁADKA, n.ż. 1651 (RNP II 123 - od mrzygłód 'głodomorek, skapiec’: Mrzygłud, Mrzygłod, Mrzygłodek 1609), NIEDBALA 1623 (RNP II 
149 - od niedbaly 'niestaranny', nie dbać: Niedbała 1488), PLACZEK 1633, n.ż. (RNP II 252 - od placzek 'ten, co płacze': Płaczek 1440), PIEKIEL 1761 (RNP II 232 - od piekło lub od piekietko: Piekiełek), SPORK 1764 (RNP II 469 - od stp. spora, spór, 'zatarg', spory dawniej 'prędki; chętny; wydajny', też 'dość duży'; niektóre formy może też od niem. n.os. Spor, Sporn-: Spork, Sporka 1675), SROGI 1679 (RNP II 471 - od srogi 'groźny, okrutny; ogromny'), WLAZŁO 1651 (RNP II 689 - od wlazło 'wszędobylski': Wlazło 1374), ZELAZNA 1797, n.ż. (RNP II 760 - por. od żelazny: Żelazny 1388), ZIMNY 1632 (RNP II 72 - od zimny: Zimny 1395), ZNIEBASPAD 1686, ZNIEBASPADŁ 1687 (fraz. z nieba spadt), ZYWA 1679, n.ż. (RNP II 767 - od żywy);

- cechy pozytywne: ODWAZNY 1761 (RNP II 171 - od odważny 'dzielny': Odważny), MILCZEK 1626, n.ż. (RNP II 100 - od milczek 'człowiek mało mówiący’: Milczek 1478), POKORA 1637 (RNP II 269 - od pokora 'uległość': Pokora 1692), PROSTY 1645 (RNP II 300 - od prosty 'równy, zwyczajny; prawy': Prosty 1447), SMUT 1716, n.ż. (RNP II 451 - od stp. smęt 'smutek', smęcić się 'smucić się', później smutek, smutny: Smut), SZCZESNA 1702, n.ż. (RNP II 529 - od szczęście, stp. też szczeście 'pomyślność, zadowolenie': Szczesny 1422), SWIDRIGAT 1619, SWIDRYGAŁ 1637 (RNP II 586 - od stp. świdrygat 'figlarz, trzpiot': Świdrygał 1518), WESOŁY 1653 (RNP II 667 - od wesoly, stp. wiesioty: Wesoły 1786);

- cechy osób powstałe od użytych metaforycznie nazw zwierząt i roślin ${ }^{12}$ :

- od nazw ssaków: BARAN 1619 (RNP I 19 - od baran), CAPA 1674 (RNP I 67 - od cap 'kozioł; baran', też od gw. capić, czapić 'złapać, porwać': Capa 1768), CIELUCH 1649 (RNP I 94 - od cieluch 'większe cielę, byczek': Cieluch 1389), JEZYK 1668 (RNP I 352 - od jeż 'zwierzę': Jeżyk), KOT 1633 (RNP I 450 - od kot: Kot 1377), KOZA 1693 (RNP I 453 - od koza: Koza 1390), KROLIK 1610 (RNP I 468 - od królik 'mały król', także 'zwierzę z rodziny zajęcy': Królik 1383), LIS 1627 (RNP II 22 - od lis: Lis 1253), TRYK 1767 (RNP II 622 - od tryk 'baran nietrzebiony', trykać 'uderzać łbem'), ZAIĄC 1650 (RNP II 719 - od zajac: Zając 1313);

- od nazw ptaków: CZAYKA 1696, CZAIKA 1783 (RNP I 107 - od czaj$k a$ 'gatunek ptaka': Czajka 1369), GĄSIOR 1765 (RNP I 224 - od gasior 'samiec gęsi': Gąsior 1372), GLAPY 1611, GLAPA 1666 (RNP I 237 - od gw. glapa 'wrona', gw. glapić się 'gapić się'), GUŁA 1631 (RNP I 283 - od gw. guła 'indyczka': Guła), KACZA 1782 (RNP I 363 - lub od kacza 'kaczka': Kacza 1633), KANIA 1628 (RNP I 373 - od kania 'ptak drapieżny z rodziny sokołów’ lub od stp. im. Kanimir: Kania 1399), KOKOSZ 1633 (RNP I 424 -

${ }^{12}$ Wyróżnione w podgrupie „nazwy zwierząt i roślin” nazwiska powstały na zasadzie metafory wspartej na stereotypach. 
od kokosz 'kura': Kokosz 1538), KOKOSZKA 1629 (RNP I 424 - od kokoszka 'młoda kura': Kokoszka 1370), KOS 1630 (RNP I 443 - od podstawy kos-, por. kos 'ptak z rodziny drozdów': kosić, kosa: Kos 1277), KOSA 1675 (RNP I 443 - od podstawy kos-, por. kos 'ptak z rodziny drozdów': kosić, kosa: Kosa 1595), KUR 1767 (RNP I 492 - od stp. kur 'kogut': Kur 1239), KURA 1767 (RNP I 492 - od kura: Kura 1237), KURAS 1782 (RNP I 492 - od gw. kuras: Kuras 1783), KURASEK 1771 (RNP I 492 - od gw. kurasek 'młody kogut': Kurasek ), KURKA 1770 (RNP I 493 - od kurka: Kurka 1454 ), WROBEL 1767 (RNP II 704 - od wróbel, stp. wrobl 'mały ptak z rodziny łuszczaków': Wróbel 1424), WRONA 1624, WRON 1641 (RNP II 703 - od wrona 'ptak z rodziny krukowatych': Wron 1417, Wrona 1374);

- od nazw ryb, i owadów: KARAS 1639 (RNP I 377 - od karaś 'ryba z rodziny karpiowatych': Karaś 1401), MROWKA 1615 (RNP II 122 - od podstawy mrow-, por. mrówka: Mrowka), MUCHA 1702, n.ż., MUCHA 1799 (RNP II 124 - od mucha: Mucha 1362), OKOŃ 1641, OKON 1642, OKUŃ 1677 (RNP II 176 - od okoń, stp. okuń 'gatunek ryby': Okon 1440, Okuń 1204), SIKORA 1633 (RNP II 423 - od sikora 'gatunek ptaka': Sikora 1389), STONKA 1638 (od stonka);

- od część ciała zwierząt i obiektów związanych z nimi: KOKO 1623 (RNP I 424 - od koko 'jajo': Koko), DZIUBA 1654 (RNP I 174 - od dziób, dziobać: Dziuba 1500), OGON 1682 (RNP II 171 - od ogon: Ogon 1318);

- od nazw roślin: GAY 1665 (RNP I 212 - od gaić 'zielenić', dawniej 'otwierać sady', gaj 'zarośla': Gaj 1414), HABER 1781 (RNP I 70 - od chaber, haber 'bławatek, chwast': Chaber 1500, Haber 1392), JAGODA 1786 (RNP I 327 - od jagoda 'owoc': Jagoda 1493), KALINA 1615 (RNP I 368 od kalina 'gatunek drzewa o czerwonych owocach': Kalina 1407), KAPUSTA 1675 (RNP I 376 - od kapusta 'roślina warzywna': Kapusta 1318), KĘPA 1612 (RNP I 392 - od kęa 'grupa drzew; wysepka': Kempa, Kępa 1398), KOPER 1782 (RNP I 436 - od koper, stp. kopr 'roślina warzywna', też od stp., gw. koper, kopr 'miedź': Koper 1690), KRUPA 1636 (RNP I 469 - od krupa 'kasza jęczmienna': Krupa 1204), KWIATEK 1674 (RNP I 503 - od kwiat, kwiatek: Kwiatek 1136), RYDZ 1642 (RNP II 376 - od rydz 'gatunek grzyba', też od rydzy 'rdzawy': Rydz 1386), SLIWIC 1665 (RNP II 578 - od śliwa 'drzewo lub krzew owocowy': por. Sliwik), SLIWKA 1792, SZLIWKA 1791 (RNP II 578 - od śliwka 'owoc śliwy': Śliwka 1373, Sliwka), SLOMKA 1655 (RNP II 446 - od słomka ‘źdźbło słomy’: Słomka 1397, Slomka), SZAFRANEK 1612 (RNP II 518 - od szafran 'krokus; przyprawa ze sproszkowanych znamion krokusa': Szafranek 1401), SZAŁWIA 1626 (RNP II 521 - od szatwia, dawniej szałwija 'roślina ozdobna; niektóre gatunki stosowane w lecznictwie'), SZYSZKA 1613 (RNP II 572 - od szyszka 'zdrewniały kwiatostan roślin igla- 
stych': Szyszka 1398, Szyska), ZIELE 1795 (RNP II 739 - od podstawy ziel-, por. ziele, zielony, gw. ziel), ZIEMNIAK 1765 (RNP II 740 - od ziemniak 'kartofel': Ziemniak), ZIOŁEK 1610 (RNP II 739 - por. od zioło 'roślina zielona; sproszkowane części roślin mające zastosowanie w lecznictwie lub przemyśle spożywczym, ziele': Ziołek), ZYTNY 1615 (RNP II 767 - od por. przym. żytni: Żytny 1482), ŻOŁĄDZ 1635 (od żoładź).

\section{Interakcje ze światem zewnętrznym}

Apelatywy motywujące nazwiska występujące w tej grupie mogły wskazywać:

- różne czynności wykonywane przez czlowieka stale lub okazjonalnie: BABA KOŚCIELNA 1673 (RNP I 12 - od baba 'kobieta; babka'), DYBEK 1787, DYBICH 1635, DYBUCH 1626 (RNP I 161 - od dybać, dawniej też debać 'czatować, skradać się' lub od dyba 'kłoda, słup': Dybek 1567, Dybich, Dybuch), GNIECKO 1632, GNIECEK 1636, GNIECZEK 1632 (RNP I 245 - od gnieść, gniot 'gniecenie, ucisk': Gniecko), GWISDON 1625 (RNP I 287 - od gwizdać: Gwizdon), KIN 1700 (RNP I 400 - od kinać 'rosnąć, kipieć, cisnąć': Kin 1377), KOLKA 1614 (RNP I 425 - od podstawy kol-, por. koło, kót, kolić 'kołysac', kolnqcé 'ukłuć': Kolka 1265), KRUSZAK 1667 (RNP I 470 - od podstawy krusz-, por. kruszyć 'łamać', stp. krusz 'bryła, gruda, północnopolskie Krusza 'grusza': Kruszak 1426);

- przedmioty i zjawiska związane z czlowiekiem ${ }^{13}$ : ARMATKA 1798 (RNP I 10 - od armata, gw. harmata), BARDZIK 1707 (RNP I 20 - od podstawy bard-, por. barda 'topór', stp. bardo 'grzebień tkacki', bard 'poeta', gw. bardo 'wzgórze'), BELKA 1637 (RNP I 27 - od podstawy bel-, tu moga być formacje polskie, por. bela, belka, a także niem. Bell: Belka), BICZ 1789 (RNP I 34 - od bicz: Bicz 1426, Bic), DYMNIK 1644 (RNP I 163 - od dymnik 'okienko lub przewód wentylacyjny na poddaszu': Dymnik), FLASZA 1644 (RNP I 196 - od flasza 'duża flaszka'), GAŁKA 1704 (od gatka), GLICZA 1610, GLICZYN 1633 (RNP I 238 - od stp. glicza 'rodzaj szpilki do upinania włosów': Glicza 1434, Gliczyna 1391), GROSZ 1623 (RNP I 271 - od grosz 'jednostka monetarna', też od niem. Gross 'duży', w pochodnych od groch: Grosz 1386), GRUDKA 1645 (RNP I 272 - od grudka: Grudka), KALECIK 1656 (RNP I 368 - od kaleta, stp. kalita, gw. kalota dawniej 'sakiewka': Kalecik 1594), KAMIEN 1639 (RNP I 371 - od kamień: Kamień 1387), KANT 1796 (RNP I 374 - od kant 'krawędź, ostry brzeg'), KARCZ 1640 (RNP I

13 Nazwy te, użyte metonimicznie, charakteryzowały człowieka (pewna „całość”) przez związany z nim jakiś szczegół (przedmiot, zjawisko itp.). 
378 - od karcz 'pniak pozostały po ścięciu drzewa': Karcz 1370), KOZIK 1673 (RNP I 453 - od kozik 'nożyk składany': Kozik1394), KRESA 1687 (RNP I 463 - od kresa 'linia', kres 'granica');

- obiekty fizjograficzne, budowle: GORKA 1699 (RNP I 255 - od górka: Górka), TAS 1633 (RNP II 598 - od tas, tasz 'kram pod namiotem, stragan');

- dni tygodnia, miesięcy, pór roku: PIĄTEK 1616 (RNP II 229 - od piatek: Piątek 1385), MAY 1636 (RNP II 55 - od maj 'nazwa miesiąca', maić: Maj 1374);

-zjawiska atmosferyczne, ciała niebieskie: BRYZA 1765 (RNP I 53: Bryza), GWIAZDA 1611 (RNP I 287 - od gwiazda: Gwiazda 1423), GWIAZTKA 1674 (RNP I 287 - od gwiazdka: Gwiazdka), WIATR 1639 (RNP II 670 - od wiatr 'poziomy ruch powietrza': Wiatr 1426);

- nazwy potraw, positków: BOCHENEK 1768 (RNP I 43 - od bochen, bochenek: Bochenek 1389), BULKA 1635, BUŁKA 1643 (RNP I 62 - od but$k a$ : Bułka), KRUPNIK 1652 (RNP I 469 - od krupnik 'rodzaj zupy; rodzaj napoju alkoholowego', też 'człowiek produkujący lub sprzedający krupy': Krupnik 1432), KULESZA 1673 (RNP I 487 - od kulesza 'potrawa mączna': Kulesza 1405).

\section{Miejsce człowieka w społeczeństwie}

Apelatywy motywujące nazwiska w tej grupie mogły wskazywać:

- wykonywany zawód, zajmowany urząd lub stanowisko: BACAN 1798 (RNP I 13 - od baca 'stary pasterz', w pochodnych też od baczyć), BARTNIK 1680 (RNP I 20 - od bartnik 'pszczelarz'), BEDNARZ 1633 (RNP I 26 - od bednarz 'wyrabiający beczki': Bednarz 1416), BISKUP 1699 (RNP I 38 - od biskup, w stp. też biskop: Biskup 1371), CELNIK 1661 (RNP I 68 - od celnik 'poborca opłat dla państwa': Celnik 1432), CIESLA 1629 (RNP I 97 - od cieśla: Cieśla 1416), CZAPNIK 1627 (RNP I 108 - od czapnik 'rzemieślnik wyrabiający czapki': Czapnik 1447), DWORNIK 1609 (RNP I 160 - od dwornik 'rządca, sługa dworski': Dwornik 1436), DZWONARZ 1642 (RNP I 175 - por. stp. dzwoniarz 'ludwisarz, dzwonnik'), FORNAL 1768 (RNP I 199 - od fornal, dawniej też fernal, furnal 'parobek, woźnica': Fornal 1423), FORSZPAN 1788 (RNP I 199 - od gw. forczman, forszpan, forszman, foczman, foczpan 'parobek od koni, stangret'), FURMAN 1634 (RNP I 207- od furman, stp. forman 'woźnica' lub od gw. furmanek 'gwóźdź na końcu dyszla': Furmanek 1391), GAZDA 1611, GASDA 1647 (RNP I 223 - od gazda 'gospodarz, góral': Gazda 1489, Gasda), GĄSIAREK 1788 (RNP I 224 - por. gęsiarek 'pastuszek gęsi': Gęsiarek), GENERAŁ 1705 (RNP I 227 - od generał, daw- 
niej jenerat), GRABARZ 1619 (RNP I 263 - od grabarz, grobarz 'człowiek zajmujący się grzebaniem zmarłych': Grabarz 1483), IGIELNIK 1629 (RNP I 319 - od igielnik 'rzemieślnik wyrabiający igły': Igielnik), KACZMARZ 1613 (RNP I 378 - od karczmarz: Karczmarz 1413), KANTOREK 1709 (RNP I 374 - od kantor 'śpiewak kościelny', też 'biuro' lub od kantorek: Kantorek 1443), KOMORNIK 1623 (RNP I 430 - od komornik: Komornik 1348), KRÓL 1647 (RNP I 468 - od król: Król 1369), KOŁODZIEJ 1635 (RNP I 428 - od kołodziej 'rzemieślnik wyrabiający koła i wozy': Kołodziej 1330), KRAWIEC 1639 (RNP I 460 - od krawiec: Krawiec 1398), KRUPIARZ 1612 (RNP I 469 - od krupiarz 'produkujący kaszę': Krupiarz 1629), KUCHARZ 1615 (RNP I 482 - od kucharz: Kucharz 1393);

- kondycję majątkowo-spoleczną: BARĄN 1626 (RNP I 21 - od baron 'wyższy dostojnik państwowy, senator'), BAUER 1793 (RNP I 23 - od niem. Bauer 'chłop, wieśniak'), BOGATA 1786, n.ż. (RNP I 44 - od bogaty: Bogaty 1404), CHAŁUPNIK 1652 (RNP I 72 - od chatupnik 'chłop bez roli': Chałupnik 1617), CHŁOPEK 1642 (RNP I 77 - od chlop 'rolnik, kmieć': Chłop 1577), CHODZI SWIAT 1646 (obieżyświat), CZELADZ 1797 (RNP I 112 - od czeladź 'służba domowa'), PAROBIK 1643, PAROBEK 1651 (RNP II 1588 - od parobek, stuga; młodzieniec: Parobek 1588), SLACHTA 1619 (RNP II 540 - od szlachta 'klasa społeczna wyodrębniona z rycerstwa, mająca dziedziczne przywileje i prawa', stp. ślachta), ZAGRODNIK 1633 (RNP II 719 od zagrodnik 'chłop bezrolny, użytkujący tylko zagrodę i niewielką działkę': Zagrodnik 1435).

- relacje rodzinne: BABKA 1675 (RNP I 12 - od baba 'kobieta; babka'), DZIADEK 1700 (RNP I 166 - od dziadek: Dziadek 1435), DZIECINKA 1769 (RNP I 169 - od dziecinko: Dziecinka 1439), PATKA (RNP II 214 por. gw. patek 'kum, ojciec, chrzestny': Patka 1638), WUJAK 1796 (RNP II 706 - od wuj 'brat matki lub mąż ciotki': Wujak).

Omówiony przeze mnie materiał stanowi niezwykle różnorodny pod względem semantycznym zbiór. Wydzielone grupy leksykalno-znaczeniowe tylko w niewielkim stopniu oddają wielość apelatywów, które dzięki mechanizmom nominacji stały się przezwiskami apelatywnymi, dalej przezwiskami antroponimicznymi, by ostatecznie ukonstytuować się jako nazwiska. W niewielkim stopniu ukazują one również specyficzne, kulturowo-językowe cechy badanej społeczności. Co zatem jest charakterystyczne dla tej grupy i regionu, a co stanowi wartość ogólnopolską? 
Na podstawie zgromadzonego materiału nazewniczego nie zawsze można jednoznacznie odczytać informację o motywacji i sposobie nominacji osoby, np. ze względu na homonimię czy polisemię wyrazu motywującego (por. przykłady wyżej). Nie oznacza to jednak, że niemożliwa jest choćby częściowa rekonstrukcja obrazu badanej społeczności. Z analizy antroponimów wynika, że mieszkańcy terenów wiejsko-podmiejskich to ludzie, którzy dostrzegali ułomności natury ludzkiej, nazywając kogoś wprost Chytrakiem, Dlubała, Niedbała czy Piekietkiem, ale i cenili w innych szczerość, uczciwość, prostolinijność, o czym świadczą nazwiska typu: Dusza, Pokora, Prosty. Wygląd zewnętrzny charakterystyczne cechy fizyczne uwydatniano w nazwiskach typu: Brzuszko, Krowigęba, Rudy, Obrostek, Stroifąs. Ze względu na to, że analizowane nazwiska to miana osób zamieszkujących głównie tereny wiejsko-podmiejskie, duża ich część informuje o rodzaju wykonywanych prac (Dwornik, Furman, Gasiarek, Gospodarz czy Chatupnik) i stosunkach własnościowych charakterystycznych dla tych terenów (Chłopek, Komornik, Parobek czy Zagrodnik). Zgromadzone nazwiska informują również o świecie otaczającym ich nosicieli przez wskazanie na przykład na ówczesną faunę (Bak, Dorszyk, Karas, Robaszek) i florę (Dabek, Gryczka, Pokrzywa), o najbliższym ich otoczeniu, w tym o uprawianej roślinności (Zytni), hodowli zwierząt (Baran, Koza, Krolik, Tryk), spożywanych pokarmach (Groszek, Jagoda, Kapusta, Rydz, Sliwka, Szałwia, Ziemniak). Co istotne, zgromadzone nazwiska tylko w niewielkim stopniu odzwierciedlają słownictwo charakterystyczne dla Poznania i Wielkopolski. Te nieliczne przykłady to np. Forszpan 1790 (Linde I; SGP II 24 'woźnica, parobek od koni'; RNP I 199 - od gw. forczman, forszpan, forszman, foczman, foczpan 'parobek od koni, stangret'), Glapa 1623 (SGP II 80 'wrona', 'gatunek ryby', 'przezwisko na gapiowatych, głupowatych'; RNP I 237 - od gw. glapa 'wrona', gw. glapić się 'gapić się'), Guła 1631 (SGP I 145 'indyk'; RNP I 283 - od gw. guła 'indyczka': Guła), Kryk 1791 (SGP II 490 'kula, laska'; RNP I 471 - od kryka 'laska, kula dla chromego': Kryk), Lebiotka 1612 (SGP III 17 'człowiek bardzo słaby; roślina leśna’; RNP I 12), Mięsała 1652 (RNP II 93 - por. stp. gw. Mięszać: Mięszała), Mora 1634 (SGP III 113 'mara, zmora'; RNP II 115 - od podstawy mor-, por. mór 'zaraza', mor 'czarny', mora 'chorobliwy odór', morzyć: Mora 1425), Mrzygładka 1651 (SGP III 194 'rodzaj rośliny'; skąpiec; RNP II 123 - od mrzygłód 'głodomorek, skapiec': Mrzygłud, Mrzygłod, Mrzygłodek 1609), Pitula 1639 (SGP nie notuje; SGMP 327 - por. pituchna 'pobożnisia'; RNP II 246 - por. stp. Pituła 'stręczyciel': Pitula, Pituła), Stelmach 1778, Stelmaszka 1643 (SGP V 231 'kołodziej'), Włodarz 1611 (SGP VI 137 'karbowy, gumienny'; RNP II 690 - od włodarz 'zarządzający dobrami ziemskimi': Włodarz 1398). Ze współczesnego punktu widzenia przywołane apelatywy, od których powstały nazwiska, to archaizmy 
wyrazowe (wyrazy zapomniane lub wychodzące z użycia w polszczyźnie ogólnej): forszpan 'woźnica', mora 'zmora, mara, upiór', mrzygłód 'niejadek, ktoś wychudzony', stelmach 'kołodziej', stelmaszka 'żona kołodzieja'14. W nazwisku spetryfikowane zostało również dawne znaczenie wyrazu glapa ‘wrona' (współcześnie to archaizm znaczeniowy). Nie tylko w Poznaniu, ale i na obszarze obejmującym więcej niż połowę obszaru gwarowego wystapiła forma guła 'indyczka, niedorajda', będąca podstawą nazwiska Guła. W analizowanym materiale wystapiło nazwisko Bauer, pochodzące od niemieckiego apelatywu Bauer. W gwarze Poznania jest to właściwe zapożyczenie wyrazowe (przyjęte w oryginalnej formie, przystosowane tylko do polskiej wymowy i odmiany). Niewielki odsetek apelatywów motywujących nazwiska charakterystyczny jest dla innych regionów Polski, np.: Dtubała, Depta, Knychała, Kuras, Patek. Większość apelatywów motywujących nazwiska to jednak leksyka ogólnopolska.

Istotne w tym momencie jest również zaznaczenie, że przywołane w artykule nazwiska to tylko nieliczny zbiór mian odapelatywnych charakteryzujących ludność świętowojciechowską. Liczną bowiem grupę, celowo pominiętą w tym artykule, stanowią np. nazwiska odzawodowe, występujące w formie łacińskiej, typu: Auriga 1609 (od łac. auriga 'woźnica, furman' - Sondel 95), Murario 1610 (od łac. murarius 'murarz, kamieniarz' - Sondel 645), Pistor 1613 (od łac. pistor 'młynarz, piekarz' - Sondel 751) ${ }^{15}$. Nie sposób także nie wspomnieć o równie licznym zbiorze nazwisk genetycznie niemieckich, utworzonych od niemieckich apelatywów. Zbiór ten stanowią formy w postaci niemieckiej lub częściowo spolonizowane ${ }^{16}$. W wynotowanym materiale znalazły się m.in. następujące formy: Ajerman 1777 (Eiermann - Gott 246), Ambe-

${ }^{14}$ Zob. A. Walczak, Stownictwo, w: Stownik gwary miejskiej Poznania, red. M. Gruchmanowa, B. Walczak, Poznań 1999, s. 51-69.

${ }^{15} \mathrm{~W}$ badanym okresie bowiem (XVII-XVIII w.), na co zwrócił uwagę m.in. Tadeusz Skulina, wiele spośród form łacińskich pełni funkcje antroponimiczne. Celowe wydaje się zatem dalsze ich badanie, by np. stwierdzić, jaki procent łacińskich nazwisk odzawodowych przetrwał w niezmienionej (łacińskiej) postaci do dziś. T. Skulina, Antroponimiczne funkcje nazw zawodowych w XVI i XVII wieku (na materiale wielkopolskim), „Studia Polonistyczne” XVI/XVII, 1988-1989, s. 113-123.

${ }^{16} \mathrm{~W}$ mieście istniała gmina luterańska, a na przedmieściu św. Wojciecha po 1553 roku wyznaczono teren, gdzie powstawały zbory (polsko- i niemieckojęzyczne) bracia czescy. O zamieszkiwaniu zaś tych terenów przez protestantów świadczą wpisy w analizowanych księgach metrykalnych. Proboszczowie bowiem nierzadko przy nazwisku rodzica/rodziców chrzczonego dziecka bądź świadków umieszczali jednoznaczną informację typu: „[...] bapt. Annam Beatam H. H. Christiani et Eve Marianne Biszkoptow C.L. acatholicorum de Olendry Nowowieyskie [...]" - 1773/LB 1761-1789/126; ,[...] bapt. infantem Catharinam H. H. Martini et Catharina Cerpow C.L. acatholicorum molitores de Niestachowo [...]" - 1774/LB 1761-1789/133; „[...] Godfrid Wolff acatholici” - 1774/LB 1761-1789/133. 
sten 1795 (niem. ambestem 'najlepiej'; Gott nie notuje), Ameiss 1795 (niem. Ameiss 'przyjaciel'; 'insekt' - Gott 166), Brand 1787 (niem. Brand 'pożar; ogień' - Gott 205), Braun 1786 (niem. braun 'brązowy' - Gott 206), Czwingier 1763 (por. Zwinger 'międzymurze'- Gott 630), Drossel 1797 (niem. Drossel 'drozd' - Gott 240), Fiszer 1774, Fischer 1785 (niem. Fischer 'rybak' - Gott 263), Fliger 1763 (por. niem. Flieger 'lotnik'). Jak wskazują nielicznie zacytowane przykłady, nazwiska te z powodzeniem można by włączyć do wydzielonych grup semantycznych. Jednak oba typy nazwisk (łacińsko- i niemieckojęzyczne nazwiska odapelatywne, w tym odzawodowe) szczegółowo omówię w oddzielnych artykułach, stąd w niniejszej pracy zaznaczam jedynie ich obecność w zgromadzonym przeze mnie materiale.

Ze względu na budowę językową poddane analizie nazwiska odzwierciedlają ogólnopolskie tendencje. Stanowią je bowiem nazwiska odapelatywne równe wyrazom pospolitym (rzeczownik bak > nazwisko Bak, przymiotnik bogaty, rudy > nazwisko Bogaty, Rudy: już w formie zsubstantywizowanej); utworzone od wyrazów pospolitych w płaszczyźnie antroponimicznej (głównie przez dodanie sufiksów do rzeczowników, ale i przymiotników, i czasowników, np. Powat-ka < powalać, powalić, Syk-orz < sykać, a także przez derywację paradygmatyczna, tj. zmianę typu odmiany fleksyjnej, np. Grota < grot); nieliczną grupę stanowią złożenia powstałe z połączenia dwóch rdzeni lub zestawienia dwóch wyrazów, np. Farbiwoda 1633, Łamiogon 1632, Mrzygłodka 1651 n.ż., Skoczylas 1703, Stroifas 1698, Topirybka 1647, Wielgogłowicz 1645, Wozignoy 1609, Woziwodka 1689, seria zestawień dwóch wyrazów: Stary Fornal 1786, Stary Kaczmarz 1790, Stary Owczarz 1796, Stary Włodarz 1787; tylko jeden przykład poświadczony dwukrotnie ma postać zdania: Zniebaspad, Zniebaspadt, również jeden ma strukturę wypowiedzenia: Pierwszy do roboty.

Nazywanie osób przy użyciu wyrazu pospolitego wiązało się zazwyczaj z ekspresywną i subiektywną oceną jednego człowieka przez drugiego. Stąd procesowi nominacji poddawane były najczęściej wyrazy wartościujące psychiczne i fizyczne cechy człowieka. W kategoriach dobry - zły oceniano również jego zachowanie. Cechy te wyrażane były wprost przez epitety, np. Mity, Wesoly (: mity, wesoly), lub za pomocą metafory i metonimii, np. Lis (bo chytry jak lis), Kapusta (bo jadał lub hodował kapuste). Tego typu przezwiska odnoszą się do jednego nosiciela, w momencie jednak, gdy wystapi przeniesienie indywidualnej nazwy osobowej na członków rodziny, rozpoczyna się proces tworzenia nazwiska. W zgromadzonym materiale proces ten jest widoczny, a nawet powszechny (por. nazwiska Bacan $<$ Bacanowa, Bednarek $<$ Bednarka, Człapa < Człapina, Gayda < Gaydzianka, Glapa < Glapina, Topirybka $<$ Topirybrzanka, Topirybczyna, Topirybczanka, Tragarz < Tragarka, Wielgogłowiecz $<$ Wielgogłowiczewa, Wielgogłowiczowa). Oznacza to, że mamy tu do 
czynienia również ze stopniowym zacieraniem się znaczenia podstawy motywacyjnej oraz zanikiem nacechowania nazwiska. Staje się ono nazwą ekspresywnie neutralną ${ }^{17}$.

Jak pokazuje zgromadzony materiał, do sfery proprialnej języka przedostały się apelatywy, które charakteryzowały człowieka głównie przez porównanie go do zwierząt, roślin czy przedmiotów. W ten sposób w procesie nominacji określały one cechy fizyczne i psychiczne, a więc takie jak wygląd, charakter, usposobienie czy intelekt. Duża grupa tychże nazwisk ma negatywne znaczenie (konotacyjne). Jak często się podkreśla, odapelatywna, pejoratywna kreacja antroponimiczna jest cechą mian o proweniencji ludowej, dlatego też nie dziwi fakt, że w analizowanym materiale przeważają nazwiska utworzone od apelatywów uwypuklających niedostatki urody, ciała, ułomności natury ludzkiej, że w nazwiskach odbicie znalazły nazwy wskazujące na ludzi krzyczących, wybuchowych, wszczynających awantury, że przez nie wypomniano takie wady człowieka, jak lenistwo, chytrość, prostactwo czy mściwość. Na tym tle z niską frekwencją występują formy wskazujące na pozytywne cechy charakteru, usposobienia i zachowania (też cechy moralne).

\section{Spis skrótów}

Gott - Gottschald M., Deutsche Namenkunde, Berlin 1954.

Linde - Linde S.B., Słownik języka polskiego, t. 1-6, Warszawa 1951.

RNP - Rymut K., Nazwiska Polaków. Słownik historyczno-etymologiczny, t. 1-2, Kraków 1999-2001.

SGMP - Stownik gwary miejskiej Poznania, red. M. Gruchmanowa, B. Walczak, Poznań 1999.

SSTO - Stownik staropolskich nazw osobowych, red. W. Taszycki, t. 1-6, Wrocław 1965-1983, Suplement - t. 7, oprac. pod kier. M. Malec, Wrocław 1953-2002.

Sondel - Sondel J., Słownik tacińsko-polski dla prawników i historyków, Kraków 1997.

SGP - Karłowicz J., Słownik gwar polskich, t. 1-6, Kraków 1900.

Sstp - Słownik staropolski, t. 1-9, red. S. Urbańczyk, Wrocław-Kraków 1953-2000.

SXVI - Słownik polszczyzny XVI wieku, t. 1-28, red. M.R. Mayenowa, Wrocław 1966-2000 .

${ }^{17}$ Por. A. Cieślikowa, Miejsce przezwiska w systemie antroponimicznym (historia a wspótczesność), w: Przezwiska i przydomki w językach stowiańskich, „Rozprawy Slawistyczne” 14, cz. 1, red. S. Warchoł, Lublin 1998, s. 71-79. 


\section{Aneta Kołodziejczyk-Trawińska \\ The Society of Poznań from the Onymic Perspective - Preliminary Research Reconstruction}

As yet, there have been no comprehensive study on the historical anthroponymy of Poznań and Great Poland. On the map of Poland this region constitutes a kind of terra incognita. The article presented is a part of the project whose objective is to compile names and surnames of the inhabitants of Great Poland. The conclusions included in the article have a character of a research reconnaissance and concern the 17th and 18th-century surnames of the inhabitants of the left-bank Poznan (the names have been excerpted from birth certificates of the parish of St. Adalbert).

The article presents Polish surnames formed as a result of appellative nomination. Since the semantics of the derivative stems of the studied anthroponyms is tightly connected with the world of plants and animals as well as the material and cultural manifestations of the community described in the article, the people's surnames have been divided into 4 groups according to: 1) external attributes, 2) psychic features, 3 ) interactions with the outer world, 4) position of a person in the society. The conclusions drawn on the basis of the analysis can be summarised as the following theses: 1) the material collected is semantically heterogeneous, 2) the reasons for choosing a particular name are not always obvious, 3 ) the material gathered only slightly reflects the cultural and linguistic specific character of the studied community, 4) the majority of appellatives motivating surnames belong to general Polish vocabulary. 
